Original article

\title{
Scent marks left by Nannotrigona testaceicornis at the feeding site: cues rather than signals ${ }^{1}$
}

\author{
Veronika M. SCHMIDT ${ }^{\mathrm{a} *}$, Ronaldo ZUCCHI ${ }^{\mathrm{b}}$, Friedrich G. BARTH ${ }^{\mathrm{a}}$ \\ a University of Vienna, Biocenter, Department of Neurobiology and Behavioral Sciences, Althanstr. 14, \\ 1090 Vienna, Austria \\ b University of São Paulo, FFCLRP, Department of Biology, Avenida Bandeirantes 3900, 14040-901 Ribeirão \\ Preto, SP, Brazil
}

Received 16 August 2004 - Revised 9 October 2004 - Accepted 12 October 2004

Published online 1 June 2005

\begin{abstract}
In order to examine whether Nannotrigona testaceicornis deposits chemical attractants at a food source we made the bees choose between a feeder where nestmates had fed before and a clean unused feeder. $86 \pm 5 \%$ of the bees chose the used feeder over the clean one. The attractiveness of the used feeder was reduced but not lost when the sugar water itself was scented by adding rosewood essence. When presenting the bees at a known feeding site a choice between a feeder on which 20 bees had walked incidentally at the nest entrance independent of food uptake and a clean feeder, a significant majority of bees chose the first one. Obviously, Nannotrigona testaceicornis leaves chemical cues on any object it walks on. These cues also attract bees from other nests of the same species and thus are not colony-specific.
\end{abstract}

stingless bee / Nannotrigona / foraging / recruitment / chemical cue

\section{INTRODUCTION}

In order to increase the colony's food intake social insects commonly either mark the food source itself with attractive scents (Ferguson and Free, 1979; Free and Williams, 1983; Schmitt and Bertsch, 1990; Nieh, 1998; Cammaerts and Cammaerts, 2000; Aguilar and Sommeijer, 2001; Schmidt et al., 2003; Hrncir et al., 2004) and/or lay a scent trail on the way from a food source to the nest (Lindauer and Kerr, 1958; Kerr et al., 1963; Wilson, 1971; Hölldobler and Wilson, 1990; Jarau et al., 2004b).

In stingless bees the marking of a valuable food source with attractive scents helps the foragers both to relocate used food sources (Aguilar and Sommeijer, 2001) and to attract other workers (Villa and Weiss, 1990; Nieh, 1998; Schmidt et al., 2003; Hrncir et al., 2004). Recently scent marks at the food source in Melipona seminigra have been identified as footprints (Hrncir et al., 2004) and the pheromones they contain were shown to be produced in the glandular epithelium of the claw retractor tendon (Jarau et al., 2004a). In stingless bees it is not known, however, whether the attractive footprints are deposited by the foragers specifically to signal the existence of a rich food source to nestmates or rather left incidentally on any object when merely walking over it.

Footprints account for the attractive marking of food sources in honeybees and bumblebees as well (Butler et al., 1969; Ferguson and Free, 1979; Free and Williams, 1983; Schmitt and Bertsch, 1990; Schmitt et al., 1991) and honeybees are indeed attracted by objects contaminated with footprints even when no bee had fed on the object before (Butler et al., 1969; Ferguson and Free, 1979).

The present study was undertaken with Nannotrigona testaceicornis, a stingless bee which

* Corresponding author: veronika.schmidt@univie.ac.at

1 Manuscript editor: Stan Schneider 
does not lay a scent path (Kerr, 1969; Hubbel and Johnson, 1978; Allerstorfer and Barth, unpublished data) despite its close phylogenetic relationship (Camargo and Pedro, 1992; Michener, 2000) to the genus Scaptotrigona showing this behavior (Lindauer and Kerr, 1958; Kerr et al., 1963). We asked (i) whether this species leaves an attractive scent at the food source, (ii) whether the scent of the food itself interferes with the attractiveness of the scent marks, (iii) whether scent marks are colonyspecific, and in particular (iv) whether they are incidentally deposited cues or true signals specifically shaped by natural selection (Seeley, 1989; Krebs and Davis, 1993).

\section{MATERIALS AND METHODS}

The experiments were carried out on the Ribeirão Preto campus of the University of São Paulo, Brazil, in March and April 2004. We used two unrelated colonies of Nannotrigona testaceicornis Lepeletier 1836. The bees were trained to a feeding site $25 \mathrm{~m}$ south-west (colony A) and $25 \mathrm{~m}$ east of the nest (colony B), respectively. At the feeding site there was an artificial feeding station (Jarau et al., 2003), mounted upon a tripod $80 \mathrm{~cm}$ above the ground on a $40 \times$ $20 \mathrm{~cm}$ wooden plate. During periods without experiment the bees could forage ad libitum at this training-feeder where they found unscented sugar water at a concentration of $35 \% \mathrm{w} / \mathrm{w}$ (ca. $1.2 \mathrm{~mol} / \mathrm{L}$; Weast et al., 1989).

During experiments the training feeder was removed. Instead, a droplet of $35 \%$ sugar water $(<1 \mathrm{~mL})$ was offered at the center of a plexiglassplate $(\mathrm{d}=6.5 \mathrm{~cm})$. All the items were cleaned with 92.8\% alcohol before an experiment and the concentration of the sugar water was controlled with a refractometer (Krüss Optronic HR 25/800).

To examine whether foraging bees of Nannotrigona testaceicornis leave any chemical markings on a feeding site, we marked four foragers individually and captured all the other bees visiting the feeding site. The four marked foragers landed on the clean plexiglass plate to feed on the droplet of sugar water at its center. After a total of 20 visits we captured them and released all the other bees. The feeder now used by their nestmates was shifted $10 \mathrm{~cm}$ either to the right or to the left of the original feeding site (midline of the wooden plate) and an identical but alcohol-cleaned unused plexiglass plate was placed $10 \mathrm{~cm}$ from the midline to the opposite side (distance between the two feeders $=20 \mathrm{~cm}$ ). Thus, the bees now returning to the feeding site had the choice between the used and the unused feeder. The test series was once carried out with unscented sugar water (unrefined cane sugar with $99.8 \%$ sucrose) and once with artificially scented sugar water $(10 \mu \mathrm{L}$ rosewood essence / $100 \mathrm{~mL}$ sugar water).

To find out whether scent marks left at the feeder are cues deposited independently of the actual feeding we made the bees walk over a clean plexiglass plate in front of the nest entrance. For this purpose the plastic entrance tube $(\mathrm{d}=1.5 \mathrm{~cm})$ could be opened on its lower side. The bees now had to step on the plexiglass plate on their way into or out from the nest. The plate was kept there until 20 bees had run over its full length. Immediately thereafter it was offered at the known feeding site to the bees, which had previously been captured and only released before the start of the experiment, together with a clean but otherwise identical plate. To test whether scent marks attract conspecific workers from another nest we offered the plate on which 20 bees from colony A had walked on to bees from colony $\mathrm{B}$ at their known feeding site. Apart from this last test series, all the experiments were carried out with bees from colony A.

All experiments followed the same procedure. After treatment of the experimental feeder (either 20 foraging visits or 20 runs at the nest exit) a droplet of fresh sugar water (residues of used sugar water were removed) was offered at the center of the plexiglass plates. The positions of the experimental feeder and the clean control feeder were exchanged every $5 \mathrm{~min}$. The experiment started when the first bee fed on one of the feeders. It lasted for $20 \mathrm{~min}$ during which every landing bee was captured. Individuals landing while another bee was on the feeder were not recorded for analysis. After each experiment all the captured bees were marked and henceforth only the decisions of unmarked bees were counted to avoid pseudoreplications. In control experiments the bees could choose between two identical alcohol-cleaned feeders each with a droplet of unscented sugar water.

Rarely the bees deposited anal excretions on the plate during the experiments (always before taking up the food). In these cases we wiped off the excretion with an alcohol-soaked cotton swab.

SigmaStat 2.0 was used for statistical analysis. Each test series consisted of six individual experiments. The percentage of the total number $(n)$ of bees $\left(n_{c}\right.$ at clean feeder $+n_{e}$ at experimental feeder $=\mathrm{n}=$ $100 \%$ ) was used to describe the distributions of bees at the feeders. In the case of a normal distribution (Kolmogorov-Smirnov-test, $P>0.05$ ), the data are presented as mean percentages $( \pm \mathrm{SD})$, whereas the median percentage (1. quartile/3. quartile) is given when the K-S-test failed. In control experiments with two identical clean feeders, the feeder with more landings was classified as A-feeder. The $\chi^{2-}$ test was used to examine whether the number of bees 


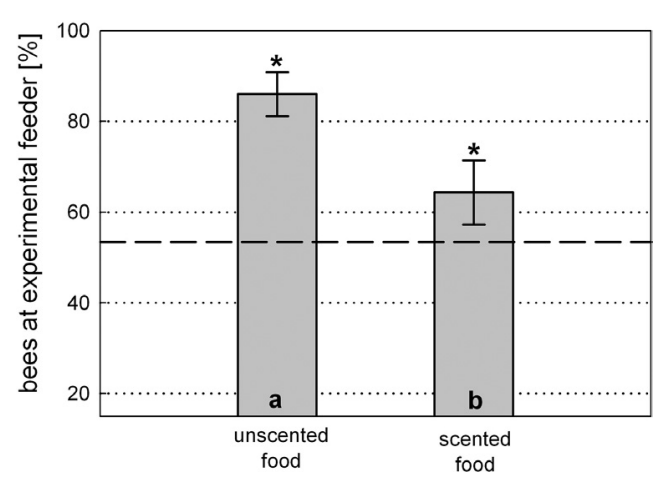

Figure 1. Attractiveness of a used feeder after 20 foragers had visited it. The mean percentage $( \pm$ SD) of bees landing on this feeder (vertical bars) is shown in comparison to the mean percentage of bees choosing one out of two clean feeders (dashed line). Asteriks mark significant differences to the control group and different letters represent significant differences between the test series (ANOVA, Tukeys pair wise comparison, $P<0.05$ )

landing at the A-feeder was significantly different from the number of bees at the other identical feeder. We conducted a one-way ANOVA followed by multiple pairwise comparisons (Tukey-test) (Sokal and Rohlf, 1995) to find out whether the differences in the percentage of the bees choosing the experimental feeder were significant among the different treatments (20 visits, unscented food; 20 visits, scented food; 20 runs at own nest-entrance; 20 runs at other colony's entrance) and whether each of these treatment-groups were significantly different from the percentage of bees at the A-feeder during control tests.

\section{RESULTS}

A food source that had already been visited by foragers of Nannotrigona testaceicornis was highly attractive to their nestmates. In neither of the six control experiments the bees preferred one of two identical feeders $\left(\chi^{2}\right.$-tests; $\mathrm{N}=6 ; P>0.45)$. A significantly larger percentage of bees (Tukey-test, $\mathrm{q}=13.26 ; \mathrm{N}=6 ; P<$ 0.05 ) chose a feeder previously visited 20 times by nestmates (unscented sugar water, $86 \pm$ $4.85 \% ; \mathrm{n}=15.5 \pm 4.8)$ as opposed to the clean control A-feeder $(53.4 \pm 3.57 \% ; \mathrm{n}=17.7 \pm 7.3)$ (Fig. 1). When the food was artificially scented with rosewood essence the used feeder (20 visits) was still significantly more attractive $(64.34 \pm$ $7.06 \% ; \mathrm{n}=20.3 \pm 8.3$ ) than the A-feeder during control tests (Tukey-test, $\mathrm{q}=4.45 ; \mathrm{N}=6 ; P<$ $0.05)$. It was significantly less attractive than during the test series with unscented food (Tukey-test, $\mathrm{q}=8.12 ; \mathrm{N}=6 ; P<0.05$ ) (Fig. 1), however.

An object became attractive when bees merely walked on it, even without feeding. After 20 bees had run over the plexiglass plate while leaving or entering their nest it was preferred to a clean plexiglass plate by nestmates searching for food at the known feeding site $(71.55 \pm 7.19 \% ; \mathrm{n}=20 \pm 8.7)$ (Tukey-test, $\mathrm{q}=$ 7.38; $\mathrm{N}=6 ; P<0.05)$. This attractiveness remained when conspecific bees from another nest had run over the plate $(72.71 \pm 6.6 \% ; \mathrm{n}=$ $23.5 \pm 12.6$ ) (comparison with control: Tukeytest, $\mathrm{q}=7.86 ; \mathrm{N}=6 ; P<0.05$; comparison with plate from their own nest: Tukey-test, $\mathrm{q}=0.45$; $\mathrm{N}=6 ; P>0.05$ ) (Fig. 2A). We conclude that the plates held scent marks which are not colony-specific and deposited unintentionally as cues by foragers walking on them without any association with the uptake of food.

Nevertheless, after 20 runs at the nest exit the plates were less attractive than plates visited 20 times by nestmates during feeding (Tukeytest, $\mathrm{q}=5.88 ; \mathrm{N}=6 ; \mathrm{P}<0.05$ ) (Fig. $2 \mathrm{~A}$ ). The difference may have been due to the different length of time spent by the bee on the feeder. The median time $\operatorname{span}[20.25(16.3 / 21.7) \mathrm{s} ; \mathrm{n}=$ 10] a forager needed to land, take up food, and leave the feeder was significantly longer than that spent by a bee just running over it when leaving or entering the nest [3.84 (2.2 / 6.4) s; $\mathrm{n}=10]$ (Mann-Whitney rank sum test, $\mathrm{T}=$ 508.0; $P<0.05$ ) (Fig. 2B).

\section{DISCUSSION}

From our results we draw four conclusions: (i) A feeding site used by Nannotrigona testaceicornis holds highly attractive scent marks. (ii) The attractiveness is not lost when the food itself is scented. (iii) The scent marks left by the bees are not colony-specific but also attract conspecific workers from another nest. (iv) Scent marks are cues rather than signals and deposited incidentally independent of feeding.

(i) Attractive scent marks left on feeding sites are common in social bees (honeybees: Butler et al., 1969; Ferguson and Free, 1979; Free and 

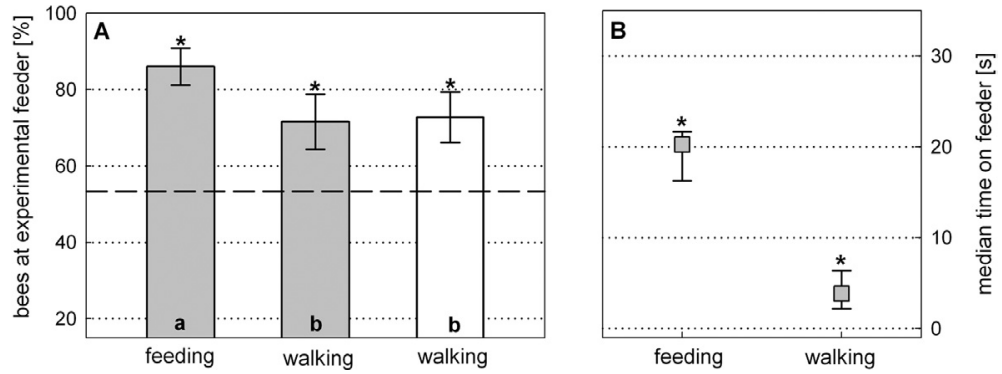

Figure 2. (A) The feeder on which bees had walked was attractive to food searching bees of the same nest and to conspecifics of another nest (asterisks mark significant differences to the clean A-feeder [dashed line] from control tests; ANOVA, Tukeys pair wise comparison, $P<0.05$ ). Grey bars: data from colony A. White bar: bees of colony B choosing a feeder treated by bees of colony $\mathrm{A}$. The attractiveness of a feeder on which bees had walked incidentally was lower than that of a feeder they actually had fed on (different letters indicate that $P<0.05$; ANOVA, Tukeys pair wise comparison). (B) Bees spent a significantly longer time on the plexiglass plate when actually feeding than while merely walking over it (Mann-Whitney U-test, $P<0.05$ ).

Williams, 1983; bumblebees: Schmitt and Bertsch, 1990; Schmitt et al., 1991; stingless bees: Villa and Weiss, 1990; Nieh, 1998; Aguilar and Sommeijer, 2001; Nieh et al., 2003; Schmidt et al., 2003; Hrncir et al., 2004). Within the stingless bees such scent marks received most attention in the genus Melipona (Nieh, 1998; Aguilar and Sommeijer, 2001; Nieh et al., 2003; Hrncir et al., 2004; Jarau et al., 2004a). They help the bees to orient towards a food source within distances ranging from $1 \mathrm{~m}$ (Hrncir et al., 2004) to $6 \mathrm{~m}$ (Nieh, 1998).

Phylogenetically, Nannotrigona is not closely related to Melipona (Camargo and Pedro, 1992; Michener, 2000). Its communication about food sources outside the nest, however, is similar to that of Melipona. Both genera do not lay scent paths to guide newly recruited bees to a used food source (Melipona: Lindauer and Kerr, 1958; Nieh and Roubik, 1995; Hrncir et al., 2000; Nannotrigona: Kerr, 1969; Hubbel and Johnson, 1978; Allerstorfer and Barth, unpublished data). The chemical guideposts they do use are only effective in the near field of the feeding site. The markings of Nannotrigona testaceicornis were significantly more attractive ( $t$-test, $t=11.29 ; P<0.001)$ than those of Melipona seminigra (Hrncir et al., 2004). 86\% of food searching Nannotrigona testaceicornis chose a used feeding site over a clean one as compared to $48 \%$ in Melipona seminigra (in both cases after 20 visits of the feeder and a distance of $20 \mathrm{~cm}$ between experimental and control feeder). In M. seminigra the used (and marked) feeder proved to attract nestmates only after at least 30 landings by the foragers (Hrncir et al., 2004). The glandular origin of the scent marks has not been studied in Nannotrigona testaceicornis, but we can exclude the importance of anal droplets and of the sugar water itself.

The level of attractiveness of a used feeding site in Nannotrigona testaceicornis even exceeded that of Scaptotrigona aff. depilis (71 $\pm 9 \%$; again after 20 preceding visits and a distance of $20 \mathrm{~cm}$ between the two feeders; $t$-test, $t=3.57$; $P<0.01$ ) (Schmidt et al., 2003). Different from Melipona the genus Scaptotrigona is closely related to Nannotrigona phylogenetically (Camargo and Pedro, 1992; Michener, 2000). Scaptotrigona, however, lays a scent path to guide recruits to a food source (Lindauer and Kerr, 1958; Kerr et al., 1963). Bees of this genus additionally mark feeding sites chemically thereby achieving an impressively precise orientation of the recruits (Schmidt et al., 2003). Within the two closely related species the effect of chemical markings at the feeding site was significantly stronger in the "non scent paths species" (Nannotrigona testaceicornis) as if the markings made up for the lack of other chemical guideposts.

(ii) The attractiveness of odorous food sources is intensified by scent mark deposition. In Nannotrigona testaceicornis the effectiveness of scent marks at the food source was reduced but not lost when the sugar water was scented. The same was found for M. seminigra (Hrncir et al., 
2004). In M. panamica food scent did not reduce the effect of scent marks at all (Nieh, 1998).

(iii) In former studies the effectiveness of the attractants was demonstrated on the colony level only (Villa and Weiss, 1990; Nieh, 1998; Nieh et al., 2003; Schmidt et al., 2003; Hrncir et al., 2004). In the present study scent marks deposited by conspecifics from another colony attracted food searching bees as much as did the scent marks of their own nestmates. We conclude that the scent marks are effective on the species level. Their species specificity still has to be examined.

(iv) Signals are commonly defined as stimuli that convey information and have been molded by natural selection to do so, whereas cues carry information only incidentally (Seeley, 1989). According to our study with N. testaceicornis the attractiveness of used feeding sites is not or only to a minor degree due to (still unknown) chemical signals, which a forager would deposit intentionally to attract nestmates. Any feeder, on which bees had walked on, attracted food searching bees of the same species, even when no bee had fed on it before. Obviously, chemical cues are deposited incidentally whenever bees run over an object. The same is known for honeybees (Butler et al., 1969; Ferguson and Free, 1979). The question whether the significantly higher attractiveness of the feeding site from which Nannotrigona had indeed taken up food was due to the longer time spent by a feeding bee on the feeder as compared to a bee just running over it or whether a bee left additional attractive chemical signals while feeding cannot be answered yet.

Here we examined the importance of scent marks to attract stingless bees in the immediate surroundings of a known feeding place. Further studies have to clarify the influence of the attractants on search flights of newly recruited bees not knowing the location of a food source, except the information possibly received inside the nest from recruiting foragers.

\section{ACKNOWLEDGEMENTS}

We thank Sidnei Mateus for his unfailing help with the maintenance of the colonies. Our work was supported by FWF-grants (P14328 and P17530) and the Karl von Frisch prize awarded to FGB, and a grant of the bmbwk of Austria to VMS. All experiments comply with the current Brazilian laws.

Résumé - Marques odorantes laissées par Nannotrigona testaceicornis sur le lieu de nourrissement : des indications plutôt que des signaux. Les marques odorantes attractives à la source de nourriture peuvent augmenter la consommation alimentaire de la colonie d'abeilles. Elles aident les butineuses à trouver une source de nourriture déjà exploitée (Aguilar et Sommeijer, 2001) et servent à attirer d'autres membres de la colonie (Villa et Weiss, 1990 ; Nieh, 1998 ; Nieh et al., 2003 ; Schmidt et al., 2003 ; Hrncir et al., 2004). On n'a jamais recherché jusqu'à présent chez les abeilles sans aiguillon si les marques odorantes à la source de nourriture sont de véritables signaux de communication («signals »), i.e des signaux porteurs d'une information et façonnés par la pression de sélection en liaison avec un effet donné chez le receveur, ou de simples indications ( « cues ») qui comportent une information non intentionnelle du donneur.

(i) On a d'abord donné le choix à des abeilles qui cherchaient de la nourriture entre un nourrisseur déjà utilisé 20 fois par des membres de la colonie et un nourrisseur propre, non visité. La grande majorité des abeilles ( $86 \%$ ) ont choisi le premier nourrisseur (Fig. 1), qui portait les marques odorantes attractives. L'attractivité de ces marques a été plus forte que chez les deux autres espèces déjà étudiées de la même façon, Scaptotrigona aff depilis (Schmidt et al., 2003) et Melipona seminigra (Hrncir et al., 2004).

(ii) Les marques odorantes gardait une action attractive significative si l'on utilisait de l'eau parfumée (10 $\mu \mathrm{L}$ essence de bois de rose/100 $\mu \mathrm{L}$ d'eau) : $64 \pm$ $7 \%$ des abeilles qui cherchaient de la nourriture ont choisi le nourrisseur déjà visité par les membres de la colonie.

(iii) Le marquage olfactif à la source de nourriture a agi aussi fortement sur les abeilles du même nid que sur les abeilles d'un autre nid de la même espèce (Fig. 2A). On montre ainsi pour la première fois chez les abeilles sans aiguillon que le marquage n'est pas spécifique à la colonie.

(iv) Afin de répondre à la question principale (vrais signaux ou simples indications), le nourrisseur a été installé à l'entrée du nid de sorte que les butineuses devaient marcher dessus lorsqu'elles entraient ou sortaient, sans rapport direct avec le nourrissement proprement dit. Lors du choix les abeilles ont significativement préféré le nourrisseur marqué de la sorte au nourrisseur propre et inutilisé (Fig. 2A). L'émission des substances odorantes attractives n'est donc pas en rapport avec la prise de nourriture en soi, les marques odorantes étant visiblement déposées dès qu'une abeille marche sur un support. Nous tirons quatre conclusions de nos résultats: (i) Nannotrigona testaceicornis dépose à la source 
de nourriture des marques odorantes attractives. (ii) L'attractivité ne disparaît pas lorsque la source de nourriture est parfumée, (iii) elle n'est pas spécifique à la colonie et (iv) il s'agit d'indications et non de véritables signaux de communication dans le sens donné plus haut.

abeille sans aiguillon / Nannotrigona / butinage / recrutement / indication chimique

Zusammenfassung - Duftmarken, die Nannotrigona testaceicornis am Futterplatz hinterlässt: eher Hinweis statt Signal. Attraktive Duftmarken an der Futterquelle können den Futtereintrag einer Bienenkolonie erhöhen. Sie helfen den Sammelbienen beim Auffinden einer bereits benutzten Futterstelle (Aguilar und Sommeijer, 2001) und dienen zudem dem Anlocken weiterer Nestgenossinnen (Villa und Weiss, 1990; Nieh, 1998; Nieh et al., 2003; Schmidt et al., 2003; Hrncir et al., 2004). Bisher wurde nicht untersucht, ob bei stachellosen Bienen Duftmarken an der Futterquelle echte Kommunikationssignale sind (,signals“), d.h. durch Selektionsdruck im Zusammenhang mit einem bestimmten Effekt beim Empfänger entstandene informationstragende Signale, oder nur Hinweise (,cues"), die vom Sender unbeabsichtigte Information beinhalten. In der vorliegenden Arbeit wird gezeigt, dass Nannotrigona testaceicornis an Futterstellen attraktive Duftmarken hinterlässt, deren Wirksamkeit vom Eigenduft des Futters abhängt und nicht koloniespezifisch ist. Zudem wird der Nachweis erbracht, dass die Duftmarkierungen keine echten Signale, sondern „cues“ sind. Dazu wurden die folgenden Experimente durchgeführt. (i) Zunächst wurde futtersuchenden Bienen die Wahl zwischen einem von Nestgenossinnen bereits 20 mal besuchten und einem reinen, unbenutzten Futterteller geboten. $86 \%$ der Bienen wählten den ersteren (Abb. 1), der demnach attraktive Duftmarken trägt. Die Attraktivität dieser Duftmarken war stärker als bei Scaptotrigona aff. depilis (Schmidt et al., 2003) und Melipona seminigra (Hrncir et al. 2004), den anderen bisher auf die gleiche Weise getesteten Arten. (ii) Die anziehende Wirkung der Duftmarkierungen war auch bei Verwendung von beduftetem Zuckerwasser signifikant ( $10 \mu \mathrm{L}$ Rosenholz-Essenz/100 mL Zuckerwasser): $64 \pm 7 \%$ der futtersuchenden Bienen wählten den bereits von Nestgenossinnen besuchten anstatt des reinen, unbenutzten Futtertellers (Abb. 1). (iii) Duftmarkierungen am Futterteller wirkten auf Bienen des selben Nestes ebenso stark wie auf Bienen eines anderen artgleichen Nestes (Abb. 2A). Damit wurde erstmals für stachellose Bienen gezeigt, dass die Markierungen nicht koloniespezifisch sind. (iv) Zur Beantwortung der Hauptfrage der vorliegenden Arbeit, ob die chemischen Markierungen echte Signale (,signals“) oder nur Hinweise (,,cues“) sind, wurde der Futterteller so an den Eingang des Bienennestes ange- bracht, dass Sammelbienen beim Eintritt bzw. Verlassen ihres Nestes über diesen laufen mussten, also ohne direkten Bezug zur eigentlichen Futteraufnahme. Im Wahlexperiment bevorzugten die Bienen den derart markierten Futterteller signifikant gegenüber einem unbenutzten, sauberen Futterteller (Abb. 2A). Die Abgabe von attraktiven Duftmarken hängt demnach nicht mit der Futteraufnahme per se zusammen. Offensichtlich werden die Duftmarken hinterlassen, sobald eine Biene über einen Gegenstand läuft. Sie sind deshalb „cues“ und nicht als echte Kommunikationssignale im oben genannten Sinn zu bewerten.

Stachellose Biene / Nannotrigona / Futtersuche / Rekrutierung / chemische Hinweise

\section{REFERENCES}

Aguilar I., Sommeijer M.J. (2001) The deposition of anal excretions by Melipona favosa foragers (Apidae: Meliponinae): behavioural observations concerning the location of the food sources, Apidologie $32,37-48$.

Butler C.G., Fletcher D.J.C., Watler D. (1969) Nestentrance marking with pheromones by the honeybee Apis mellifera L., and a wasp, Vespula vulgaris L., Anim. Behav. 7, 142-147.

Camargo J.M.F., Pedro S.R.M. (1992) Systematics, phylogeny and biogeography of the Meliponinae (Hymenoptera, Apidae): a mini-review, Apidologie 23, 509-522.

Cammaerts M.C., Cammaerts R. (2000) Foraging area marking in two related Tetramorium ant species (Hymenoptera: Formicidae), J. Insect Behav. 13, 679-698.

Ferguson A.W., Free J.B. (1979) Production of a forage-marking pheromone by the honeybee, J. Apic. Res. 18, 128-135.

Free J.B., Williams I.H. (1983) Scent-marking of flowers by honeybees, J. Apic. Res. 22, 86-90.

Hölldobler B., Wilson E.O. (1990) The ants, Springer, Berlin Heidelberg New York.

Hrncir M., Jarau S., Zucchi R., Barth F.G. (2000) Recruitment behavior in stingless bees, Melipona scutellaris and $M$. quadrifasciata. II. Possible mechanisms of communication, Apidologie 31 , 93-113.

Hrncir M., Jarau S., Zucchi R., Barth F.G. (2004) On the origin and properties of scent marks at the food source by a stingless bee, Melipona seminigra, Apidologie 35, 3-13.

Hubbel S.P., Johnson L.K. (1978) Comparative foraging behavior of six stingless bee species exploiting a standardized resource, Ecology 59, 1123-1136. 
Jarau S., Hrncir M., Schmidt V.M., Zucchi R., Barth F.G. (2003) Effectiveness of recruitment behavior in stingless bees (Apidae, Meliponini), Insectes Soc. 50, 365-374.

Jarau S., Hrncir M., Ayasse M., Schulz C., Francke W. Zucchi R., Barth F.G. (2004a) A stingless bee, Melipona seminigra, marks food sources with a pheromone from its claw retractor tendons, J. Chem. Ecol. 30, 793-804.

Jarau S., Hrncir M., Zucchi R., Barth F.G. (2004b) The stingless bee Trigona recursa uses labial gland secretion for scent trail communication, J. Comp. Physiol. A 190, 233-239.

Kerr W.E. (1969) Some aspects of the evolution of social bees, Evol. Biol. 3, 119-175.

Kerr W.E., Ferreira A., De Mattos N.S. (1963) Communication among stingless bees - additional data (Hymenoptera: Apidae), J. N.Y. Entomol. Soc. 71, 80-90.

Krebs J.R., Davies N.B. (1993) An introduction to behavioral ecology, 3rd ed., Blackwell Science, Oxford.

Lindauer M., Kerr W.E. (1958) Die gegenseitige Verständigung bei den stachellosen Bienen, Z. Vgl. Physiol. 41, 405-434.

Michener C.D. (2000) The bees of the world, John Hopkins University Press, Baltimore, London.

Nieh J.C. (1998) The role of a scent beacon in the communication of food location by the stingless bee, Melipona panamica, Behav. Ecol. Sociobiol. 43, 47-58.
Nieh J.C., Roubik D.W. (1995) A stingless bee (Melipona panamica) indicates food location without using a scent trail, Behav. Ecol. Sociobiol. 37, 63-70.

Nieh J.C., Ramírez S., Nogueira-Neto P. (2003) Multisource odor-marking of food by a stingless bee, Melipona mandacaia, Behav. Ecol. Sociobiol. 54, 578-586.

Schmidt V.M., Zucchi R., Barth F.G. (2003) A stingless bee marks the feeding site in addition to the scent path (Scaptotrigona aff. depilis Moure 1942), Apidologie 34, 237-248.

Schmitt U., Bertsch A. (1990) Do foraging bumblebees scent-mark a food source and does it matter? Oecologia 82, 137-144.

Schmitt U., Lübke G., Francke W. (1991) Tarsal secretion marks food sources in bumblebees (Hymenoptera: Apidae), Chemoecology 2, 35-40.

Seeley T.D. (1989) Social foraging in honey bees: how nectar foragers assess their colony's nutritional status, Behav. Ecol. Sociobiol. 24, 181-199.

Sokal R.R., Rohlf F.J. (1995) Biometry, 3rd ed., Freeman, New York.

Villa J.D., Weiss M.R. (1990) Observations on the use of visual and olfactory cues by Trigona spp foragers, Apidologie 21, 541-545.

Weast R.C., Lide D.R., Astle M.J., Beyer W.H. (1989) CRC Handbook of Chemistry and Physics, 70th ed., CRC Press, Boca Ranton Florida.

Wilson E.O. (1971) The insect societies, Harvard University Press, Cambridge. 